\title{
A tribute to Rosalyn S. Yalow
}

n May 30, 2011, after a decade and a half of physical and cognitive decline, Rosalyn S. Yalow died, just before her ninetieth birthday. Two days later on a green hillside in New Jersey, a short drive from the Bronx, a dozen intimates gathered to bid farewell. After a round of informal testimonials and traditional recitations, we took turns gently shoveling earth to cover the pine box that protected her remains. The rhythm of the shovels, the camaraderie of the mourners, and the glow of the sun brought forth kaleidoscopic flashbacks - Stockholm, Atlantic City, and the Bronx.

Rosalyn Yalow lived nearly all of her life in the Bronx, where she was born, educated and worked, raised her family and met Solomon Berson, her scientific partner for many years (1). Yalow and Berson were born in New York, children and grandchildren of immigrants from Europe (1-3). For both families finances were constrained due to shortage of capital, anti-Semitic impediments to employment, and the Great Depression. Both Berson and Yalow were educated in New York City public schools. Berson graduated from the legendary City College of New York, then all-male and tuition-free. After graduation, it took him three years (earning a master's degree and working as an assistant in the New York University Anatomy Department) before he broke through the extreme barriers then in place for Jewish applicants to medical school. Berson bragged about his hundred or more medical school rejections. A classmate of Berson at New York University School of Medicine recalled that on Day One it was obvious to all that Berson would be the leading student in their class.

Yalow was a top student at Hunter College, the tuition-free, all-female counterpart of City College, where she majored in physics. Despite a brilliant record, she failed to gain admission to any graduate programs in physics, specifically and openly because she was female and Jewish. Finally, as a favor to one of her Hunter College professors, the University of Illinois accepted her into their $\mathrm{PhD}$ program in nuclear physics with the condition that they bear no responsibility for placing her in a job after graduation. Indeed, despite a brilliant school record and the World War II shortage of civilian males, employment for her was spotty. It was two years before she joined the Veterans Administration Hospital ("Bronx VA") as a consultant and five years until she was hired as a full-time physicist $(1,2)$.

Through talent, hard work, and good luck, in 1950 Ros became the fledgling head of the nascent radioisotope unit at the Bronx VA. Novel applications of radioisotopes to medicine were burgeoning. She developed a solid program of service, teaching, and research but recognized that to reach its full potential the unit needed a physician. After the rejection of many candidates, Bernard Straus, the highly regarded chief of the medical service, introduced Ros to the smartest MD he had ever trained. After an hour, Ros was certain that Sol Berson was the smartest MD she had ever met (1).

\section{Novices teach one another}

The two novices taught one another how to do research (1-3). Soon, they were publishing in first-line journals. When their elegant studies of radioactively labeled albumin were upstaged by Ken Sterling's prior publication, they turned to insulin, one of the few other pure proteins available. In the fateful experiment, the actual result was the opposite of the expected result. Radioactively labeled insulin disappeared from the circulation of the diabetic patients at a slower rate than in normal subjects - due to heretofore unsuspected anti-insulin antibodies in the blood of patients who had received insulin therapy (4). Use of the term "antibody" in that 1956 paper led to its initial rejection by the JCI. (That JCI rejection is probably more famous than the rejection by Nature of the 1937 Krebs paper

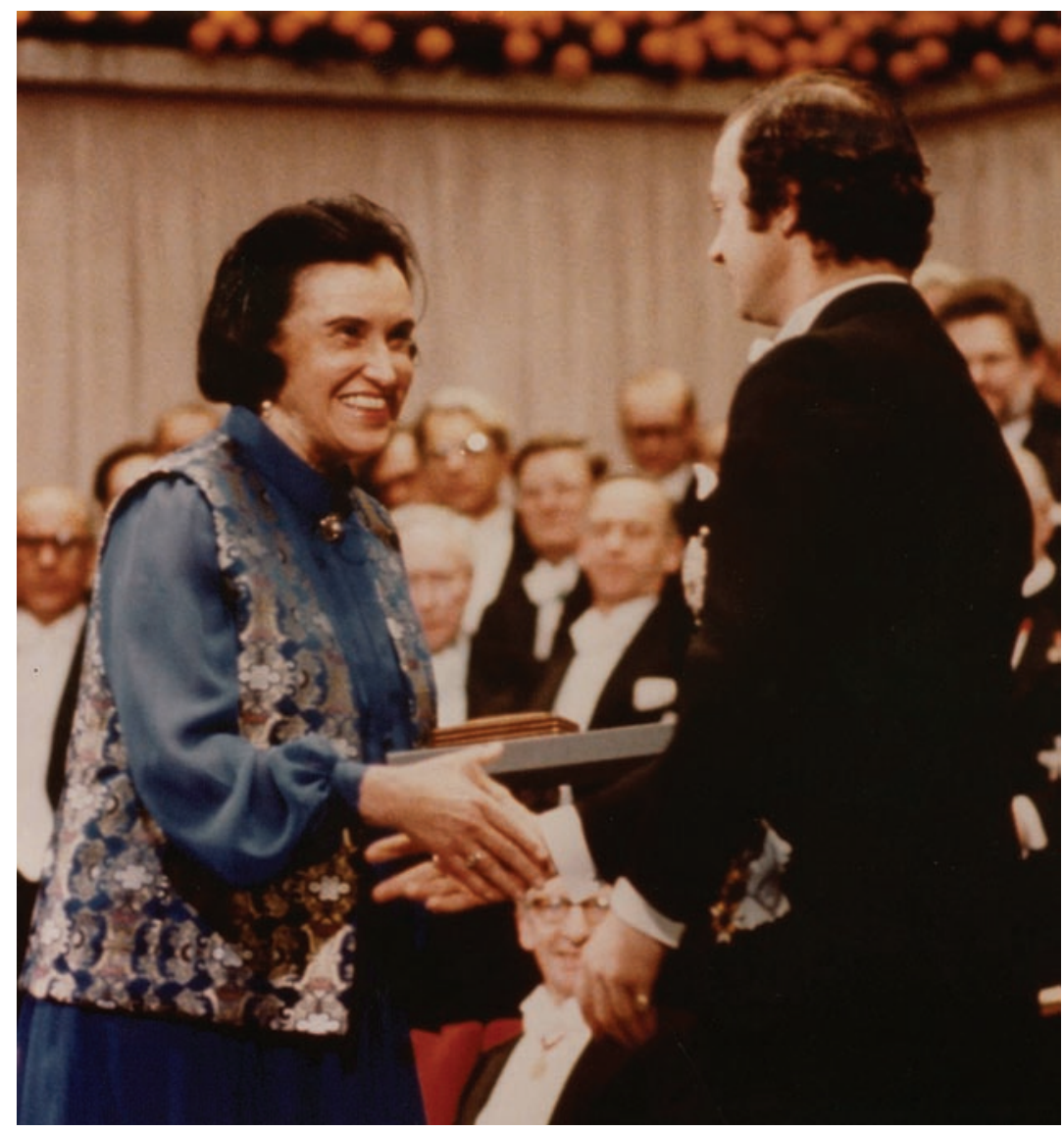

\section{Figure 1}

Rosalyn S. Yalow accepting the Nobel Prize in Physiology or Medicine presented by King Carl XVI Gustaf of Sweden on December 10, 1977. Photo courtesy of Ben Yalow. 
describing the citric acid cycle.) Yalow and Berson then studied anti-insulin antibodies in great detail, leading them to create the radioimmunoassay only ten years after they first teamed up $(5,6)$.

Late in the afternoon of May 2, 1960, as part of the plenary session of the 52nd annual meeting of the American Society for Clinical Investigation, the most prestigious venue for new biomedical science, Ros strode to the podium, introduced by Society president Robert Berliner. Over the next ten minutes, with a dozen 5 -inch by 5 -inch glass slides hand fed into a carbon arc light projector, she showed the 4,000 academic researchers crowded into the musty auditorium of the old Steel Pier in Atlantic City how she and her research partner, Berson, had managed to measure the amount of insulin in a fraction of a milliliter of whole plasma from 100 patients undergoing glucose tolerance tests. The physiological insights were novel and enlightening, but the cognoscenti among the audience immediately recognized that they were witnessing a major revolution in all of endocrinology. For the first time since the work of early pioneers of endocrinology such as Claude Bernard and Oskar Minkowski, the amount of a hormone in blood could be measured - with precision and specificity.

The 19-page article in the JCI of July 1960 with all of the details of the assay remains one of the journal's most highly cited papers $(6,7)$. Besides being a blueprint for those who wished to measure insulin, it rapidly became the indispensable guide to pioneers who, along with Yalow and Berson, adapted the method to all other peptide hormones and extensions beyond endocrinology.

\section{Explosion of assays}

In 1961, fourteen months after the first public presentation of radioimmunoassay, Seymour (Shimon) Glick and I arrived to start postdoctoral fellowships at the Bronx VA with Yalow and Berson. By then Roger Unger in Dallas had reported an immunoassay for glucagon. Sheldon Rothenberg, working in the Yalow-Berson lab, extended the method by using intrinsic factor to measure vitamin $B_{12}$. Based on the synergy of his partnership with Yalow, Berson enthusiastically encouraged Glick and me to work together to develop an immunoassay for growth hormone. Our two mentors were there in the lab working all the time - at the bench doing experiments, writing speeches and papers, reviewing our data, and teaching us (1-3).
By early 1963, our fledgling immunoassay gave a burst of new findings about growth hormone as an acute metabolic hormone (8). Although Yalow and Berson were essential full partners in our development of the growth hormone work, they shunted the credit and the speaking invitations to Glick and me. Simultaneously, the four of us began work on the ACTH immunoassay (9), while "the bosses" were also debuting the parathyroid hormone radioimmunoassay with the NIH's Gerald Aurbach and John Potts, who had just purified the human hormone. Selna Kaplan and Mel Grumbach, under the tutelage of the two masters, were introducing their immunoassay of human placental lactogen. Immunoassays were pouring forth throughout the field. Glick moved to Brooklyn, where he pioneered the immunoassay of oxytocin. Berson helped me find an excellent spot at the NIH in Bethesda, where I worked on immunoassays for vasopressin and the pituitary gonadotrophins.

The radioimmunoassay for insulin led to assays of countless proteins and peptides, as well as a very broad range of other biological molecules, e.g. drugs, steroids, cyclic AMP, and viruses. All could be measured with high sensitivity and specificity, even in complex biological fluids (10). Typically each new assay added novel biological insights and novel tools for the management of human diseases. Among individual assays, the largest effect on human welfare was likely derived from the method's extension to viruses, specifically hepatitis B (11) and HIV. In addition to their essential role in diagnosis, the tests prevented life-threatening transfusion-borne infections. No listeners in May 1960 or readers in July of that year, even those with a hypertrophied prophetic sense, could have imagined the extent of this revolution, not only in endocrinology but also in all of biology and medicine.

From 1963 to 1973 , my most important new work at the NIH was introducing, with Ira Pastan and colleagues, the concept and methods for studying cell surface receptors: first ACTH, followed by insulin and then growth hormone (12, 13). Crucial to this work was the deep sophisticated knowledge I brought with me from the Bronx of (a) the intricacies of labeling peptides with radioactivity at high specific activity, (b) quantitative methods for measuring hormone interac- tions with other proteins, and (c) swift, convenient approaches to separating free from protein-bound labeled hormones. Also, as Pastan and I embarked on our earliest receptor studies, we incorporated insights we had gained from Berson's acerbic critique of Stadie's pre-modern studies (14).

\section{Berson's death and aftermath}

In April 1972, suddenly and unexpectedly, Sol Berson died of a massive heart attack while attending a FASEB meeting in Atlantic City, just a few days before his 54th birthday (1-3). Grief was everywhere - for the Berson family, for the Yalow family, and for Berson's many colleagues and admirers. Soon, we realized that a collateral loss might be the endocrine community's Nobel expectations for Berson and Yalow.

Yalow was grief stricken at the loss of her research partner and possibly of her Nobel dreams (1). Good fortune placed Eugene Straus, son of Bernard Straus, in Yalow's lab as a fellow. In addition to providing vital psychological support, he energized the lab's research (1). Over the next several years (1973-1977), the pair produced a substantial corpus of new studies of hormones from the gastrointestinal tract and the brain (1). This remarkable burst of new work won over any doubters - it was then widely recognized that Yalow herself was a fully worthy laureate.

My most vivid image is Ros Yalow (Figure 1), clad in a brilliant blue evening dress, stepping forward to accept her Nobel Prize from Sweden's King Carl XVI Gustaf $(1,2)$. That evening in the Grand Hall of the Swedish Academy, representing all of the Nobel laureates, Ros responded eloquently to the traditional challenge to the awardees from the university students of Sweden (2). A couple of days earlier in her Nobel Lecture at the Karolinska Institute, she recounted the scientific work that led to this special moment, including the vital role played by her scientific partner, the late Solomon Berson (1-3). Once again she showed a slide that included the famous 1956 letter from JCI's editor-in-chief Stan Bradley rejecting Yalow and Berson's earliest paper on antibodies to insulin (4, 7). At each event I was there applauding along with her family (husband Aaron and children Ben and Elanna) and colleagues Eugene Straus, Roger Unger, Harold Rifkin, and Susan Roth (1). 


\section{End of an era}

We relatives, friends, former students, and colleagues will carry with us our personal collections of images of this most remarkable individual. Yalow's own words (2), addressed to the university students of Sweden, will continue to inspire us:

It is all too easy to be pessimistic if we consider our multiple problems: the possible depletion of resources ... hostilities between nations ... unemployment and vast inequalities among different races and different lands. Even as we envision and solve scientific problems ... we appear ill-equipped to provide solutions for the social ills that beset us. We bequeath to you, the next generation, our knowledge but also our problems . . . let us join hands, hearts and minds to work together for their solution so that your world will be better than ours and the world of your children even better.

\section{Acknowledgments}

The author is indebted to Alessandra L. Szulc for excellent editorial assistance; to Mitchell T. Rabkin, Seymour M. Glick, Ann Danoff, Goran K. Hansson, and Seymour Reichlin for review of the manuscript and many helpful suggestions; and to Ben Yalow for the photograph published here.

\section{Jesse Roth}

Feinstein Institute for Medical Research, North Shore-Long Island Jewish Health System, Manhasset, New York, USA; Albert Einstein College of Medicine, Yeshiva University, New York, New York, USA. E-mail: jesserothmd@hotmail.com.

1. Straus E. Rosalyn Yalow, Nobel Laureate: Her Life and Work in Medicine; A Biographical Memoir. New York, New York, USA: Plenum Trade; 1998.

2. The Nobel Prize in Physiology or Medicine 1977. Nobelprize.org. http://nobelprize.org/nobel_prizes/ medicine/laureates/1977/. Accessed June 22, 2011.

3. Roth J. Solomon A. Berson. Diabetes. 1973; 22(1):66-68.

4. Berson SA, Yalow RS, Bauman A, Rothschild MA Newerly K. Insulin- $\mathrm{I}^{131}$ metabolism in human subjects: demonstration of insulin binding globulin in the circulation of insulin treated subjects. J Clin Invest. 1956;35(2):170-190.

5. Berson SA, and Yalow RS. Quantitative aspects of the reaction between insulin and insulin binding antibody: relation to problem of insulin resistance. J Clin Invest. 1959;38:1996-2016.

6. Yalow RS, Berson SA. Immunoassay of endogenous plasma insulin in man. J Clin Invest. 1960 39:1157-1175.

7. Kahn CR, Roth J. Berson, Yalow, and the JCI: the agony and the ecstasy. J Clin Invest. 2004; 114(8):1051-1054.

8. Glick SM, Roth J, Yalow RS, Berson SA. The regulation of growth hormone secretion. Recent Prog Horm Res. 1965;21:241-283.

9. Yalow RS, Glick SM, Roth J, Berson SA. Radioimmunoassay of human plasma ACTH.J Clin Endocrinol Metab. 1964;24:1219-1225.

10. Yalow RS. Radioimmunoassay: a probe for the fine structure of biologic systems (Nobel Lecture, 8 December 1977). Science. 1978;200(4347):1236-1245.

11. Walsh JH, Yalow RS, and Berson SA. Radioimmunoassay of Australia antigen. Vox Sang. 1970; 19(3):217-224

12. Roth J. Peptide hormone binding to receptors: a review of direct studies in vitro. Metabolism. 1973;22(8):1059-1073.

13. Roth J, Taylor SI. Information transfer cell regulation and disease mechanism: insights from studies of cell surface receptors. Harvey Lect. 1982; 77:81-127.

14. Newerly K, Berson SA. Lack of specificity of insulin- $\mathrm{I}^{131}$ binding by isolated rat diaphragm. Proc Soc Exp Biol. 1957;94(4):751-755. 